\title{
色の測定と色覚メカニズム*
}

内川 惠二**

\section{Color Measurement and Color Vision Mechanism}

\author{
Keiji UCHIKAWA
}

\section{1.色の“常識”は“非常識”}

私たちは外界のほとんどの情報を視覚から得ている。 私たちは自分の見ている周囲の景色を“物理的な”存在 として認識し，その存在を自分は正しく捕らえていると 感じている，たと齐ば，自分が部屋の中央にある四角い 大きな茶色の机の前に座っているとしよう．机の四角い “形”とか大きい“サイズ”とかいう机の属性は辺の長 さや角度といった物理的な客観量として表わせるが，私 たちはその物理量を正しく見ていると思っている．この ように外界の物理世界に対応した視覚世界を脳内に形成 するのがそもそもの視覚の目的であり，視覚世界が“正 しい”からこそ私たちは矛盾なく外界の物理世界に生存 できているのである。

では，机の“茶色”はどうであろうか。普通は, 誰で も形やサイズと同じように“色”もその物の属性と感じ ている，机の形やサイズが長さや角度で表わされるよう に，机の色も何らかの物理量で表わせると思っている。 物理量は誰がどこで測っても変わらないからこそ物理量 なのであるから，机をどこに持っていっても色は変わら ないと考えている，それが保証されているからこそ，商 品のカタログに示されている“色”が意味を持っている はずであると思っている。これが私たちの色の“常識” であろう。しかし，これは誤りであり，色の“非常識” なのである。

私たちの日常生活で必要な物の長さ, 重さ, 時間, 面 積, 体積, 速度といつた物理量については私たちは小, 中学校の時から良く教えられている.物の“色”も極め て日常的であり，他の物理量と同じように大切な情報で ある。しかし，なぜ，私たちは色についてほとんど教え られていないのであろうか.色の“物理的な”教育がな い, あるいはできないことが，皮肉にも私たちが色を物 の “物理的な” 属性と思ってしまうという非常識を生ん でいる，しかし，実は，この非常識の中に色の本質が潜 んでいるのである。

* 原稿受付 1996 年 10 月 28 日

** 東京工業大学工学部像情報工学研究施設

\section{2.色の “非常識”が “常識”}

‘色が物の物理属性である'という非常識に気づかず， 色について議論していくと括とらく次のようになるであ ろう。“物の表面に照明光が当たり，その反射光を私たち は見ているので，色は表面の光学的な反射特性であるに 違いない. 光の波長成分によって光の色が変わることは 良く知られているので, 表面の各波長に対する反射率, つまり分光反射率が “色”ということになる. 分光反射 率が一様ならば白色, 長波長領域に偏っているならば赤, 中波長，短波長領域に偏っていれば，それぞれ緑，青色 になる．色は分光反射率成分にほほ対応して決まってい る’ということである.あるいは，表面の色が照明光に よっても変わることに気づいている人は, ‘色は表面の分 光反射率そのものではなく，反射光の分光成分である’ と，考えるだろう。

おそらくまだかなりの人々が，このような考えを持っ ているに違いないが，残念ながら，色は表面の分光反射 率成分でもなければ，反射光の分光成分でもない。では 何か. 色は眼に入射する光を“きっかけ”にして，脳内 に生起する感覚なのである.光線そのものには色はない’ とはニュートンの有名な言葉である。'色は感賞である' が正しい答えである。

しかし，では，なぜ，私たちは“色は物の表面の特性で ある’と思ってしまっているのだろうか. また，なぜ，そ う思っていても別に困ることはないのだろうか。色をこ のように思ってしまう原因は実は“色が感覚である’から なのである.こう考えると，少しややこしく聞こえるが， 要は，脳の働きを考えれば理解できる.

私たちは脳内に外界の視覚像を形成している。これは 脳が行なっている基本的な働きであるが，このとき，脳 は，たとえば，物の長さについては，物理距離と長さの 感覚とを 1 対 1 に正しく対応付けしている. しかし，色 については, 物の表面と表面の感覚,つまり,色とを 1 対 1 に対応付けしていない. 物の長さも大きさも私たちが 見ているものは感覚である。しかし，対応がいいので， 普段は特に私たちはそれを意識する必要がない. 色はそ の対応が不完全になってしまっているので, 意識せざる を得ない状況が時々生まれる。しかし，物の認識のため 
に，脳は私たちがあたかも色が物の表面にきちんと対応 しているが如く感じるように仕向けている．また，たと えば，照明光が変化しても表面の色は変わって見えない ようにするなど，樣々な巧妙な色覚のトリックを実行し ている。その結果，“色は物の属性である’という色の“非 常識”が生まれているのである. 私たちにとっては，や はり，物が同じであればどこでもその色は同じに見えて ほしい.実は，この“非常識”が脳が意図した色の“常 識”なのである。

\section{3.“色”を測る}

色は感覚である，物理的な “光”には感覚的な“色” はない.では，この感覚としての色をどのように測った ら良いであろうか. ‘感覚が測れるのか’と, 私たちはすぐ 考えてしまう.なぜならば，これまで測るという行為は 純粋に物理的なもので，そこには常に客観性が要求され る'と教育され，感覚というような主観的なものは測る という行為にはなじまない’という考えを,私たちは暗黙 のうちに受け入れてしまっているからである.小，中学 校で “色”の物理教育がないのはこのためである，感覚 がいつまでも，“物理”ではなく“心理”で扱われている のは，この測定に問題があると私たちが詰解しているか らであろう。

感覚を測ることは学問としては心理物理学としてすで に長い歴史があり，きちんとした方法論が確立されてい る. 色の測定, すなわち, 測色学は感覚測定の中でも最 も歴史が古く発達したものである．感覚を測定すること は大変有用で, 測色学から生まれた現在の表色システム がなければ, 色彩工学の発展はなかったし, 色の利用も 極限られたものになっていたであろう。しかし，色に限 らず感賞はすべて脳の機能であるから，色を完全に表記 するには脳の機能を十分に把握しなければならない.脳 がまだわかっていない現時点では，残念ながら現在の表 色システムも完全とはいえず，色覚の 1 次近似といった ところである。このことを理解した上で使用すれば，不 完全な近似であっても色覚を測定し客観的に表現するこ とは大いに役立つことである. 本稿では，色の測定の基 礎について，特に色覚のメカニズムからの説明に重点を 置いて述べることにする。

\section{4. 等色の原理}

現在の測色学の基礎となっている原理は“等色”であ る.これは図 1 の 2 分視野を用いて，一方の視野にいか なるテスト光 $\mathrm{C}$ をってきても, 他方の視野の $\mathrm{R}, \mathrm{G}, \mathrm{B}$ 混色光の強度を調節すれば，全く等しい色の見えを作る ことができる，つまり等色できるということである。こ こで，“全く等しい色の見え”というのは，左右の視野の 明るさも色みも全く等しいことであり，もし中央の境界 線がなければ, 完全に一様な視野になってしまうことで ある. カラーCRTやカラー液晶ディスプレイが赤, 緑,

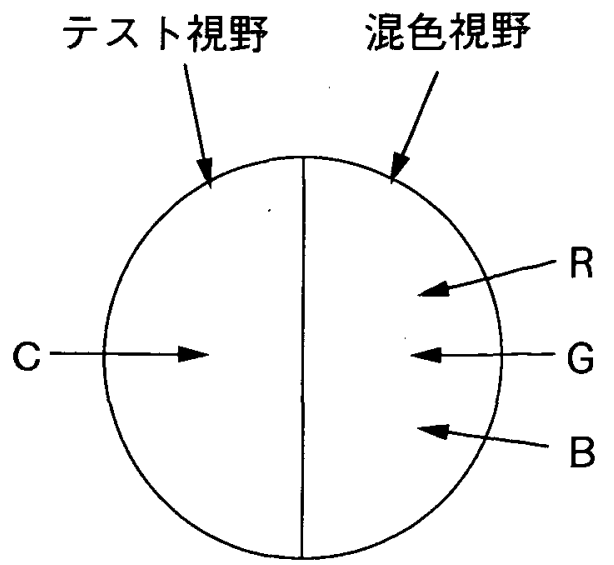

2 分視野

図 1 等色 2 分視野.テスト視野（左）に任意の色光 C, 混色視野（右）に決められた 3 原色光 $\mathrm{R}, \mathrm{G}, \mathrm{B}$ の 加法混色光が呈示される.

青の 3 種の発光体でどんな色でも作ってしまうのはこの 等色の原理が成立するからである.

等色は,

$$
\mathrm{C}=\mathrm{R}+\mathrm{G}+\mathrm{B}
$$

という等色方程式で表わす。ここで, 混色光の $\mathrm{R}, \mathrm{G}, \mathrm{B}$ は原色と呼ばれている。この等色方程式では，“+”記号 は“色光を混色する’, “=”記号は“両辺の視野が等色する” ことを意味している。

この等色の原理が成立するためには二つの条件が必要 である.一つは R, G，Bの 3 原色は互いに独立でなけれ ばならないことである.これは, 3 原色のどの一つをとつ ても他の二つで等色されてはならないという意味である。 等色方程式では

$$
R \neq G+B, \quad G \neq B+R, \quad B \neq R+G
$$

となる.この独立性の条件は, 逆に考えると, どんな 3 原 色でもこの条件さえ満たしていれば良いということにも なる， 3 原色 $\mathrm{R}, \mathrm{G}, \mathrm{B}$ は赤, 緑, 青ではなく, オレン ジ, 紫, 青緑といった任意の色光の組み合わせでもよい。 もう一つは負の混色を許すという条件である. 光は足 すことはできても, 引くことはできないので, 負の混色 とは光を引くのではなく，等色方程式の上でマイナスを 作るという意味である。もし任意の色光 $\mathrm{C}$ が 3 原色を物 理的に重ねたのでは等色されなければ, R, G, B のどれ か一つを混色視野側から取り去り, 逆にテスト視野側に 入れることで等色を成立させることができる，たとえば， $\mathrm{R}$ を混色視野からテスト視野へ移し，Cと $\mathrm{R}$ の混色光が $\mathrm{G}$ と B の混色光と等色すると,これは

$$
\mathrm{C}+\mathrm{R}=\mathrm{G}+\mathrm{B}
$$

で表される.ここで，左辺の $\mathrm{R}$ を右辺に移項して 


$$
\mathrm{C}=-\mathrm{R}+\mathrm{G}+\mathrm{B}
$$

として, - R を負の混色というのである.

任意の色光が 3 種の色光で等色できるという等色の原 理が成立するのは，色を表現するのに大変都合がいい． 任意の色光が 3 変数の組で表現でき, 単純な表色システ ムが可能となるからである．現在の CIE（国際照明委員 会) XYZ 表色システムをはじめ多くの表色システムはこ の原理に立脚している1).

\section{3 種の光受容器}

では，なぜ任意の色光を等色するには 3 種の色光が必 要で, しかも 3 種あれば十分なのだろうか.この問題を 考えるには, まず, 眼の網膜には 3 種類の分光吸収（感 度）特性を持った錐体細胞があり，ここで光を吸収する ことが色覚の出発点であること,さらに, 1 種類の錐体細 胞では，光の強度を調節してしまえば二つの波長を区別 できないことを前提知識とする2).

图 2 は左半分が等色視野のテスト光側, 右半分が混色 光側を表している.両側には 3 種の錐体 $L, M, S$ の分光 感度曲線 $L(\lambda), M(\lambda), S(\lambda)$ が描かれている. 各分光感 度は最大值で 1 に正規化されているものとする。ここで はわかりやすくするためにテスト光 C を単色光 $\lambda \mathrm{t}$ とし， その強度をIt とする。左側の視野にある錐体 $\mathrm{L}, \mathrm{M}, \mathrm{S}$ は $\lambda \mathrm{t}$ 光によってそれぞれ

$$
\begin{aligned}
& l=L(\lambda t) \cdot I t, \\
& m=M(\lambda t) \cdot I t, \\
& s=S(\lambda t) \cdot I t,
\end{aligned}
$$

の応答を出すことになる．もし，テスト光が単色光でな くあるスペクトル強度 $I(\lambda)$ を持った複合光であったな らば，それぞれの応答が

$$
\begin{aligned}
& l=\int L(\lambda) \cdot I(\lambda) d \lambda, \\
& m=\int M(\lambda) \cdot I(\lambda) d \lambda, \\
& s=\int S(\lambda) \cdot I(\lambda) d \lambda,
\end{aligned}
$$

となるだけで，本質的な違いはない。
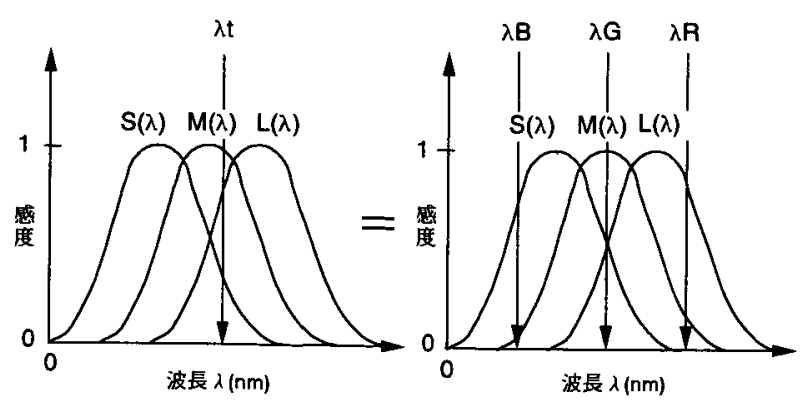

図 2 錐体応答からの等色条件の説明図. 左がテスト視 野，右が混色視野に対応する。
右側の視野の混色光 $\mathrm{R}, \mathrm{G}, \mathrm{B}$ もここでは簡単のために 単色光 $\lambda \mathrm{R}, \lambda \mathrm{G}, \lambda \mathrm{B}$ 光として, 強度をそれぞれ $I R$, $I G, I B$ とする， R, G, B が複合光であっても原理は同 じである. 錐体 $\mathrm{L}, \mathrm{M}, \mathrm{S}$ は $\lambda \mathrm{R}, \lambda \mathrm{G}, \lambda \mathrm{B}$ 光によってそれ ぞれ

$$
\begin{aligned}
& l=L(\lambda R) \cdot I R+L(\lambda G) \cdot I G+L(\lambda B) \cdot I B, \\
& m=M(\lambda R) \cdot I R+M(\lambda G) \cdot I G+M(\lambda B) \cdot I B, \\
& s=S(\lambda R) \cdot I R+S(\lambda G) \cdot I G+S(\lambda B) \cdot I B,
\end{aligned}
$$

の応答を生む. テスト光 $\lambda \mathrm{t}$ に対して混色光 $\lambda \mathrm{R}, \lambda \mathrm{G}, \lambda \mathrm{B}$ の強度を調整して, 錐体 $\mathrm{L}, \mathrm{M}, \mathrm{S}$ の応答 $l, m, s$ 左右 の視野で等しくしまえば，それ以降の視覚系は両者を全 く区別できない、これが “等色”である。したがって,

$L(\lambda t) \cdot I t=L(\lambda R) \cdot I R+L(\lambda G) \cdot I G+L(\lambda B) \cdot I B \cdots \cdots(1)$,

$M(\lambda t) \cdot I t=M(\lambda R) \cdot I R+M(\lambda G) \cdot I G+M(\lambda B) \cdot I B \cdots(2)$,

$S(\lambda t) \cdot I t=S(\lambda R) \cdot I R+S(\lambda G) \cdot I G+S(\lambda B) \cdot I B \cdots \cdots(3)$,

となる.

ここで，もし，錐体が1種類だけであったとしょう。 これを L 錐体とすると上式のうち(1)式だけが成立すれ

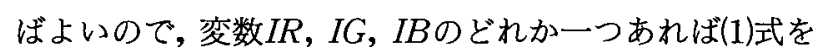
成立させることができる。次に, 2 種類の錐体だけがある とし，これを $\mathrm{L}$ 錐体と $\mathrm{M}$ 錐体とする。この場合は(1), (2) 両式を成立させなければならないので, 变数 $I R, I G, I B$ のどれかーつだけでは不可能であるが，変数が二つあれ ばよい. 最後に，3 錐体あるとすると，(1)，(2)，(3)式のす べてが成立しなければならいので, $I R, I G, I B$ の 3 変数 すべてがあることが必要十分条件となる，これは，また， 錐体は 3 種類しかないことを示している.

\section{6. 等色と錐体空間}

$\mathrm{L}, \mathrm{M}, \mathrm{S}$ 錐体の応答を 3 軸 $\mathrm{L}, \mathrm{M}, \mathrm{S}$ とした錐体空間 を考える (図 3)。任意のテスト光 $\mathrm{C} に$ 対して 3 種の錐体 $\mathrm{L}, \mathrm{M}, \mathrm{S}$ ぞれぞれ応答 $R L, R M, R S$ を出すとして,

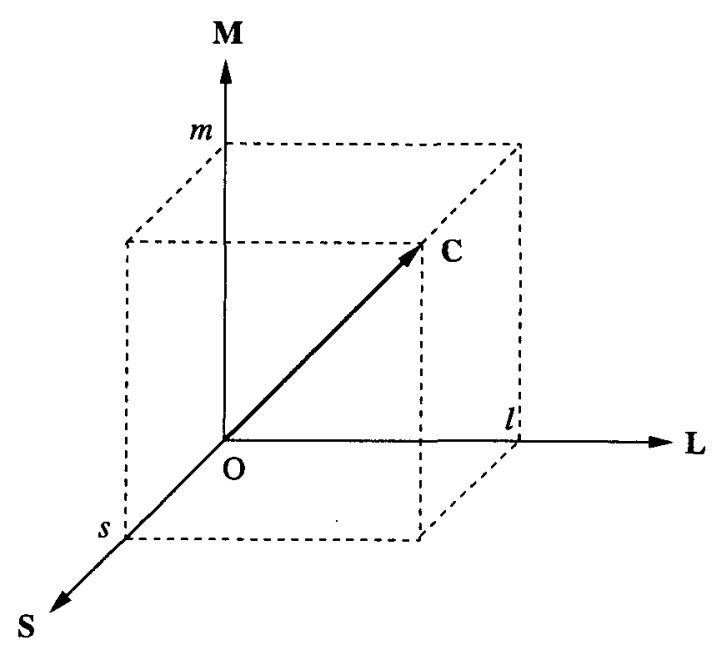

図 3 錐体空間. 色 $\mathrm{C}$ は $\mathrm{L}, \mathrm{M}, \mathrm{S}$ 軸で張られる錐体空間 の中でベクトルとして表される。 


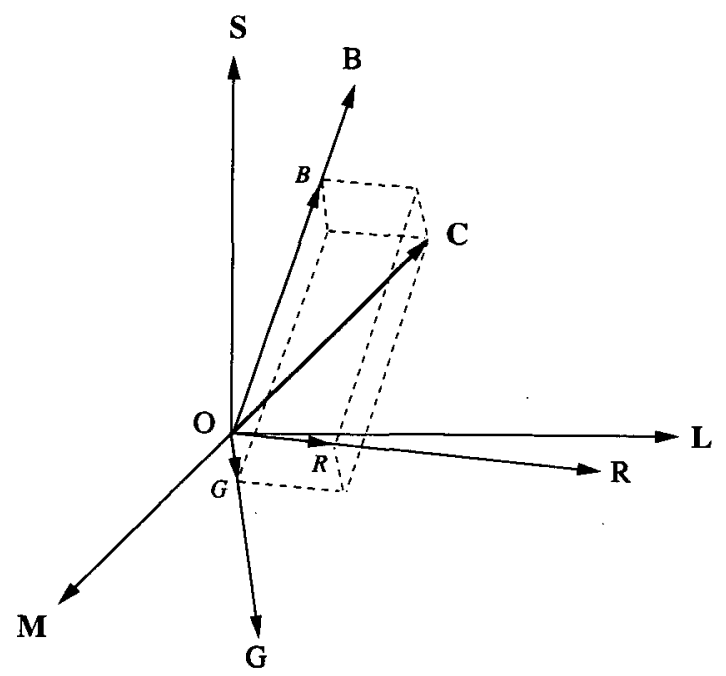

図 4 錐体空間中の色ベクトル $\mathrm{C}$ と 3 原色ベクトル $\mathbf{R}$, $\mathrm{G}, \mathrm{B}$. 色ベクトル $\mathrm{C}$ は 3 原色ベクトル $\mathrm{R}, \mathrm{G}, \mathrm{B}$ 方向の成分 $R, G, B$ を持つ.

テスト光 $\mathrm{C}$ を成分 $(l, m, s)$ を持つ 3 次元空間のベク トル C として錐体空間内に表す．どんな光でも L， M, $\mathrm{S}$ 錐体の応答で決まるのであるから，すべての光は 3 軸 の值が正の範囲内に成分をもつ色ベクトルで表現できる ことになる.

等色とは 2 色の色べクトルが数学的に等しくなること である.ここで四 4 に示すように 3 個の色べクトル $\mathbf{R}$, $\mathrm{G}, \mathrm{B}$ をとる. この $\mathrm{R}, \mathrm{G}, \mathrm{B}$ の和の色ベクトル $\mathbf{R}+\mathrm{G}+$ $\mathrm{B}$ を取り $\mathbf{R}+\mathbf{G}+\mathbf{B}=\mathbf{C}$ となるように $\mathbf{R}, \mathbf{G}, \mathrm{B}$ のそれ ぞれの長さを調節することが, 3 原色 $\mathrm{R}, \mathrm{G}, \mathrm{B}$ を用いて 色 $\mathrm{C}$ と等色することである.ベクトル $\mathrm{C}$ を作れるならば R, G, B の組み合わせはどのようなものでも良いことが 図 4 よりよく理解できるであろう。また，負の等色とは $\mathrm{C}$ が R, G, B で張る空間内の外にある場合に起こること もよくわかる， 3 原色ベクトル $\mathbf{R}, \mathbf{G}, \mathrm{B}$ をできるだけ広 く張るように取れば負の等色が少なくなる.

\section{CIE 表色システム}

色を図 4 に示すような色空間中の 1 点で表現できれば， 表色システムができたことになる. CIE 1931 RGB 表色 システムでは，L，M，S 軸を使うことはせずに，図 5 に 示すように, 混色光の $R, G, B$ 光を直光 3 軸にとってい る. $\mathrm{R}=700 \mathrm{~nm}, \mathrm{G}=546.1 \mathrm{~nm}, \mathrm{~B}=435.8 \mathrm{~nm}$ である. 色の 3 次元表示は表色の基本であり，二つ以上の色を混 色した時には必ず使わなければならないものである.

色は 3 次元表示をすれば, 完全に記述できるが, 一般 的に用いられる“色” はほとんどの場合, その色の“色 み”を意味し, 色光の強度次元に対応する “明るさ”ま で含めないのが普通である，そこで，色光の “色み”に 対応する R, G, B 成分の比にだけ注目し, その強度の次 元を落とした 2 次元の表示法が考えられた．これが色度 図である。



图 5 色 Cの色度 $(r, g)$ 。色ベクトル C \& RGB 色空間 の単位平面と点 $\mathrm{P}$ で交わる. 点 $\mathrm{P}$ の座標を色 $\mathrm{C} の$ 色度座標 $(r, g, b)$ とする.

色 C の強度次元を除くためには，図 5 に示してあるよ うに， R， G，Bで張る色空間中に $(1,0 ， 0) ，(0,1$, $0) ，(0 ， 0 ， 1)$ を通る単位面を取り，この面と色 $\mathrm{C}$ の交 点 $\mathrm{P}$ をる. 点 $\mathrm{P}$ の座標 $(r, g, b)$ が色度座標であ る. 色べクトル $\mathrm{C}$ の長さはその色の強度に対応し, ベク トルの方向がその色の色みに対応しているので，このよ うに平面と交点を取れば色みだけが取り出せるわけであ る. 色度座標 $(r, g, b)$ は色 $\mathrm{C} の R, G, B$ 成分から,

$$
\begin{aligned}
& r=R /(R+G+B) \\
& g=G /(R+G+B) \\
& b=B /(R+G+B)
\end{aligned}
$$

で計算される。このときの, $R, G, B$ 值は色の単位とな る三刺激值である。 また， $r, g, b$ には

$$
r+g+b=1
$$

の関係があり, 独立な変数は 2 個である.したがって, 色度座標としては $r, g ， b の$ 内の 2 個を用いればよい。 現在の測色学では， $\mathrm{P}(r, g, b)$ を $\mathrm{RG}$ 平面に投影した 点 $\mathrm{P}^{\prime}(r, g)$ を色 $\mathrm{C}$ の色度座標としている。

CIE ではこの RGB 表色システムをさらに使いやすく するために，X，Y，Z 軸という新しい 3 軸を RGB 空間 中に取り，CIE 1931 XYZ 表色システムを作り，同様に， $(x, y)$ 座標を定義している。これが, 現在最も良く使 われている $\mathrm{xy}$ 色度図である。

\section{8. 色覚メカニズムのモデル}

錐体以後の色覚メカニズムは図 6 に示すように，3 錐 体レベルから反対色・輝度レベルへ，さらに高次レベル へとつながっている. 反対色・輝度レベルでは 3 錐体 $\mathrm{L}$, $\mathrm{M}, \mathrm{S}$ 応答の和と差で反対色 $\mathrm{r}-\mathrm{g}, \mathrm{y}-\mathrm{b}$ 応答と輝度 $\mathrm{Lu}$ 
応答が作られる.これらの変換の具体的な計算式はモデ ルによって異なるが，いずれの場合でも和と差を取って いる.

反対色・輝度レベルは錐体から脳への色応答の伝達経 路と考えられている.なぜ，このような和と差の信号で 色応答が伝達されるのかは, 視覚の他の情報の伝達とも 関係があり, 視覚系の基本構造の問題である. 反対色応 答は高次レベルで処理されて, 色の見えとなり, 物体認 識とも関ってくる

反対色応答の一例を図 7 に示す. L, M, S 錐体からの 変換は次式のように定義されている.

$$
\begin{aligned}
r-g= & L-2 M, \text { または, } \\
& L-2 M+0.05 S, \\
y-b= & (L+M)-S, \\
L u= & L+M,
\end{aligned}
$$

ここで，L，M，S の感度は Smith-Pokorny の錐体感度 を用い, $\mathrm{L}$ と $\mathrm{M}$ 感度の相対的な高さは $r-g=L-2 M$ がュニーク黄である約 $570 \mathrm{~nm}$ で 0 になるように決め, また, $\mathrm{S}$ 感度の高さは $y-b=(L+M)-S=0$ の点が ユニーク緑である約 $500 \mathrm{~nm}$ の波長に来るように決めて

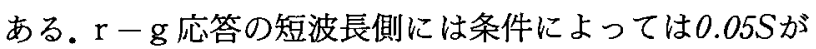
加算され，短波長側での赤みの説明に使われる.

\section{9.色の見えの変化}

色は物の表面から反射してきた色光, あるいは光源か ら直接来る色光を “きっかけ”にして生まれる視覚系の 応答であるが, 色光の分光組成が変化すれば，その色は 当然変化してもよい. しかし, 色の変化には必ずしも色

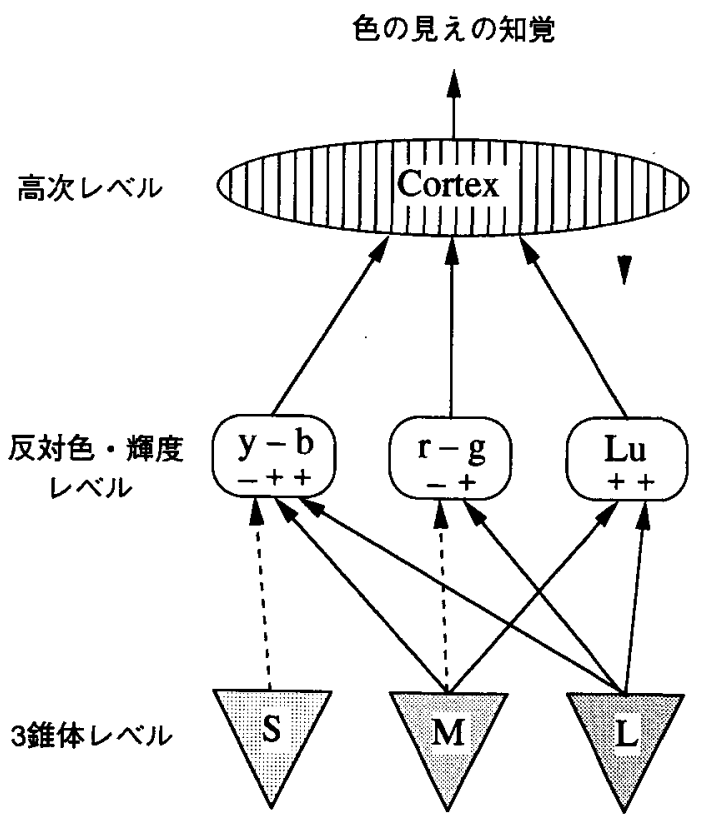

图 6 色覚メカニズムのモデル. 色覚応答は段階的に，3 錐体レベル，反対色・輝度レベル，高次レベルと処 理され，最終的に色の見えとなる。
光の分光組成の違いは必要ではない．視覚系の応答を変 化させるような他の要因があれば，色は異なってくる。

色の見えに影響をおよぼす要因は表 1 に示すように大 きく三つに分けられる. 刺激の呈示条件, 刺激の観察条 件, 刺激の認識条件である. 刺激の呈示条件は刺激その ものの輝度, サイズ, 呈示持続時間, 呈示視野位置といっ た条件であり，刺激の分光組成が同じでも，それ以外の 刺激条件が変わると色の見えは変化する．色の見えを決 める色覚のメカニズムが刺激の輝度に対して線形に働く かどうか，色覚の時空間特性が色の見えにどのように影 響しているかといったことが問題となる．刺激の観察条

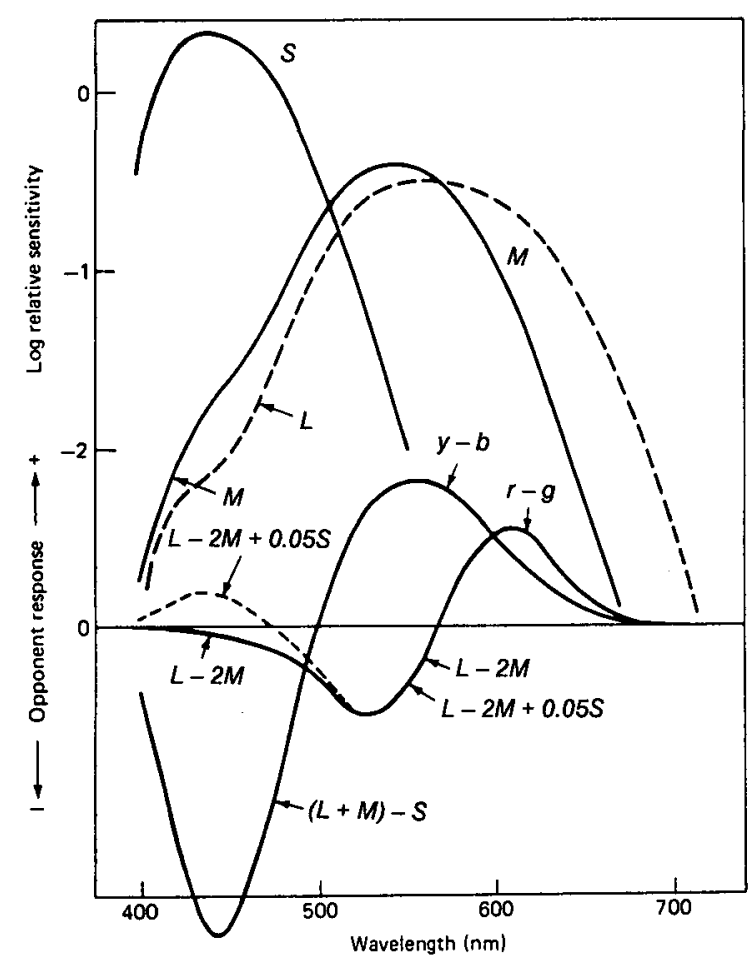

図 7 反対色応答 $\mathrm{r}-\mathrm{g}, \mathrm{y}-\mathrm{b}$ の一例. 錐体の感度は $\mathrm{L}$, $\mathrm{M}, \mathrm{S}$ で示されている.

表 1 色の見えに影響をおよばす要因

[1] 刺激の呈示条件

(1) 輝度レベル

(2) 刺激サイズ

（3）呈示持続時間

(4) 刺激視野位置

[2] 刺激の観察条件

(1) 空間対比

(2) 時間対比

(3) 色順応

[3] 刺激の認識条件

（1）色の見えのモード

(2) 色の恒常性

(3) 色のカテコ゚リー

（4）色の記憶

（5）物体認識 
件は刺激を見るときの周囲の環境条件である．刺激その ものの物理的な呈示条件は全く同じでも，色の見えはそ の周囲に何があるか，直前に何を見たか，また，環境の 照明光は何かといった条件に依存する。刺激の認識条件 は色を物の認識の一つとして捕らえる時の条件である. 刺激の色を表面の色としてみるか光の色としてみるかで 色の見えは変わり,さらに表面色では照明光が変わって も表面の色はそれ程変わって見えないという恒常性があ る.また，色をカテゴリーとして捕らえるメカニズムや 色の記憶も色の見えに影響し, 物体の奥行き視も色の見 えを左右している。

このように, 色光の分光組成は同じ, すなわち, 表色 システムでは同じ “色”を示す二つの刺激でも実際の色 の見えは異なることが多い. 要因 $[1] ，[2]$ は色覚メカ ニズムの上では錐体レベルと反対色・輝度レベルでお扔 よそ説明がつく．たとえば，刺激光のサイズを小さくし ていくと, $460 \mathrm{~nm}$ 付近の波長弁別が劣化し, 青みと黄み の色みが弱くなってくるような色の見元の変化が起こる. これは，網膜の中心部では $\mathrm{S}$ 錐体がなくなることから起 こる現象で，ちょうど S 錐体が欠損している色覚異常の 特性に類似するので，小視野トリタノープ（第三色覚異 常）と呼ばれている゙2.

要因 [3] は高次レベルの色覚メカニズムを考えないと 説明がつかないものである。ここで，例として，色の記 憶とカテゴリカル知覚を次に取り上げてみる.

\section{0. 色の基本カテゴリー}

私たちが二つの色を比較するときは, 二つの色を隣接 させて同時に見られような場合を除き，必ず一つの色を 記憶してもう一つの色と比較するというように, 色の記 憶が関与するのが普通である。たとえば，私たちが撮っ たカラー写真を後日見るときの状況を考えてみると，こ のカラー写真の色がいいとか, 正しいとか判断する場合 は, 記憶にある元の風景の色とその写真の色とを比較し ている．記憶の中で色の見えがどう変化するかは色の評 価や色再現分野などで函めて重要な問題となっている.

色の記憶のいくつかの研究 ${ }^{3-5}$ では, 色は記憶の中, つ まり高次色覚レベルでカテゴリカルに変化するというこ とが報告されている，小さい色の差が高次レべルではな くなり，大きな色カテゴりーにまとめられてしまう。並 べて見れば差がわかる二つの色も同じ色として処理され るということである.このようなカテゴリーとして 11 個 の基本色: 白, 黒, 赤, 緑, 黄, 青, 茶, 紫, オレンジ, ピンク, 灰が示されている6.

図 8 (口絵 6) は横方向に色相, 緹方向に明度の順に色 票を配置した図であるが，一つ一つの色票を見ればその 差はわかる。しかし，私たちはこれすべてを正確に記憶 することはできないし，日常的には 11 個の基本色かその 組み合わせでほとんどすべての色票を表現している.

ここで,この色票の配列をいくつかに分けてください’
と言われたら，私たちは何処に線を引くだろうか。おそ らく，ほとんどの人が共通して，左右の端をまとめて “赤”, 中央を“緑”, 左側上部に“黄”, 右奇り緑の隣に “青”というょうに，簡単にこの色票の配列を分割でき るだろう。また，このような人間のカテゴリカル色知覚 はチンパンジーにも共通であることが報告され，さらに， サルにもカテゴリカルな色知覚があることが生理学的に 示されている7.

図 9(口絵 7)（上）はある風景写真の原画で，(下）は 原画のすべての色度点を有彩色 8 色の基本色の色度点に カテゴリカルにまとめてしまった変換画像である，ただ し, 各画素の明度値はそのままにしてある。図 9(上)（下） の画像を比較すると, 原画に注様々な色相があり, 変換 画像には赤, 緑, 黄, 青, 茶, 紫, オレンジ, ピンクの 8個の色相しかないにもかかわらず，絵の印象はほとん ど変わらない。むしろ，絵は強くはっきりしているよう に見える.脳内の色賞高次レベルでは外界画像の色の見 えをカテゴリカルに処理し，その視覚像を原画像として 記憶しているのではないだろうか.

\section{1. ニれからの測色}

このように, 色の見えは様々な要因で変化するが，現 在の測色学では残念ながら色の見えまでを扱うことがで きない.この理由は, 测色学が等色という感覚测定の手 法に基礎を置いてはいるが, 必ずしも色覚のメカニズム を十分反映していないからである。これからの“色の見 え”を扱う測色学は色覚のメカニズムを積極的に取り込 んでいかなければ成り立たないことは明らかであろう。

色の測定法という実用科学と色覚のメカニズムの解明 という基礎科学はこれまでは，互いに影響しあいながら も, 独立に発展してきた. 色覚メカニズムの研究もこれ からは脳の領域に踏み込んでいかなくてはならない. 真 の意味で実用になる測色も脳のメカニズムと独立には考 えられない.

\section{参考文献}

1) G. Wyszecki and W. S. Stiles: Color Science, John Wiley and Sons (1982).

2) P. K. Kaiser and R. M. Boynton: Human Color Vision, Optical Society of America (1996).

3 ) K. Uchikawa and H. Shinoda: Influence of basic color categories on color memory discrimination, Color Res. Appl., 21 (1996) 430-439.

4) 杉山徹, 内川惠二: 色の記憶とカテゴリカル色知覚の比較, Vision, 5 (1993) 85-88.

5 ) R. M. Boynton, L. Fargo, C. X. Olson and H. S. Smallman: Category effects in color memory, Color. Res. Appl., 14 (1989) 229-234.

6 ) B. Berlin and P. Kay: Basic Color Terms: Their Universality and Evolution, Univ. of Calif. Press (1969).

7 ) 内川惠二: 科学, 65 (1995) 429-437. 


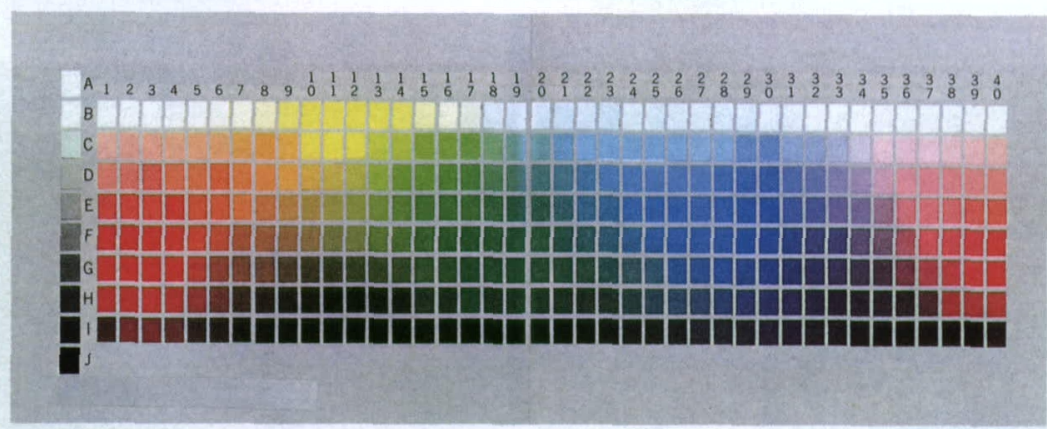

口絵 6 色票の配列

すべての色票の差も知覚できるが, 同時にすべての色票を 11 個の 基本色カテゴリー; 白, 黒, 赤, 緑, 黄, 青, 茶, 紫, オレンジ, ピンク，灰にまとめることもできる。

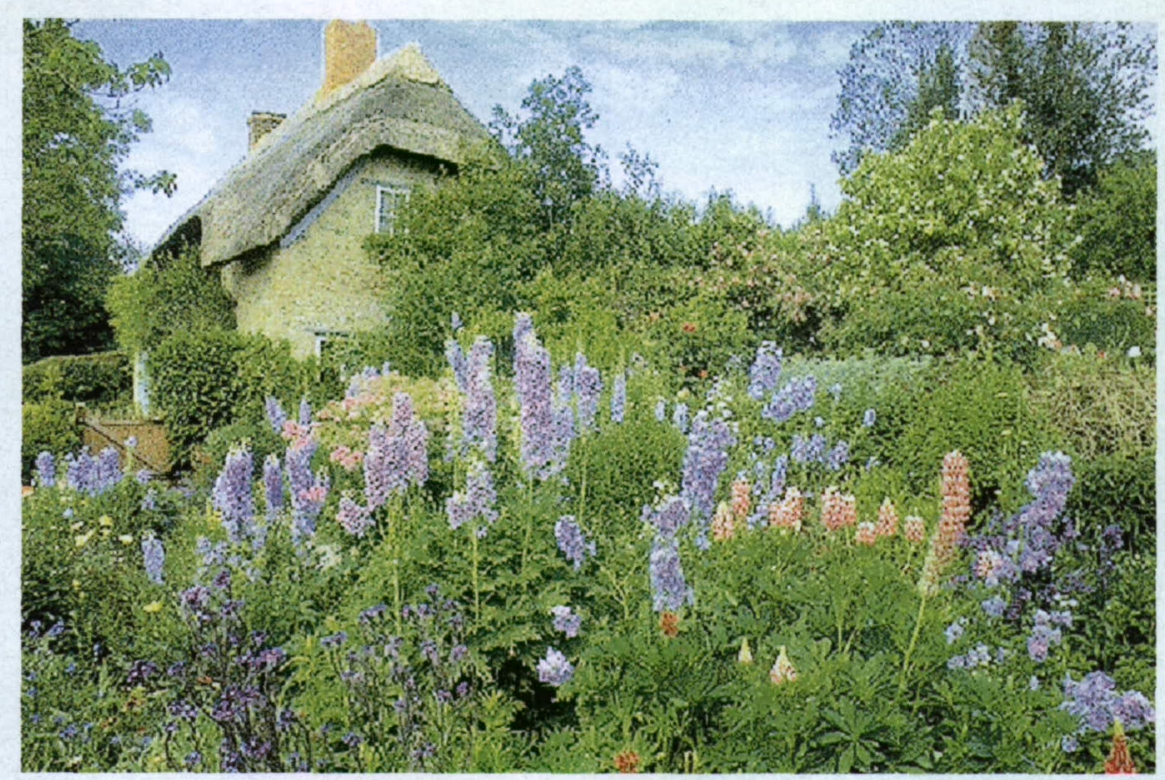

(a) 原画像

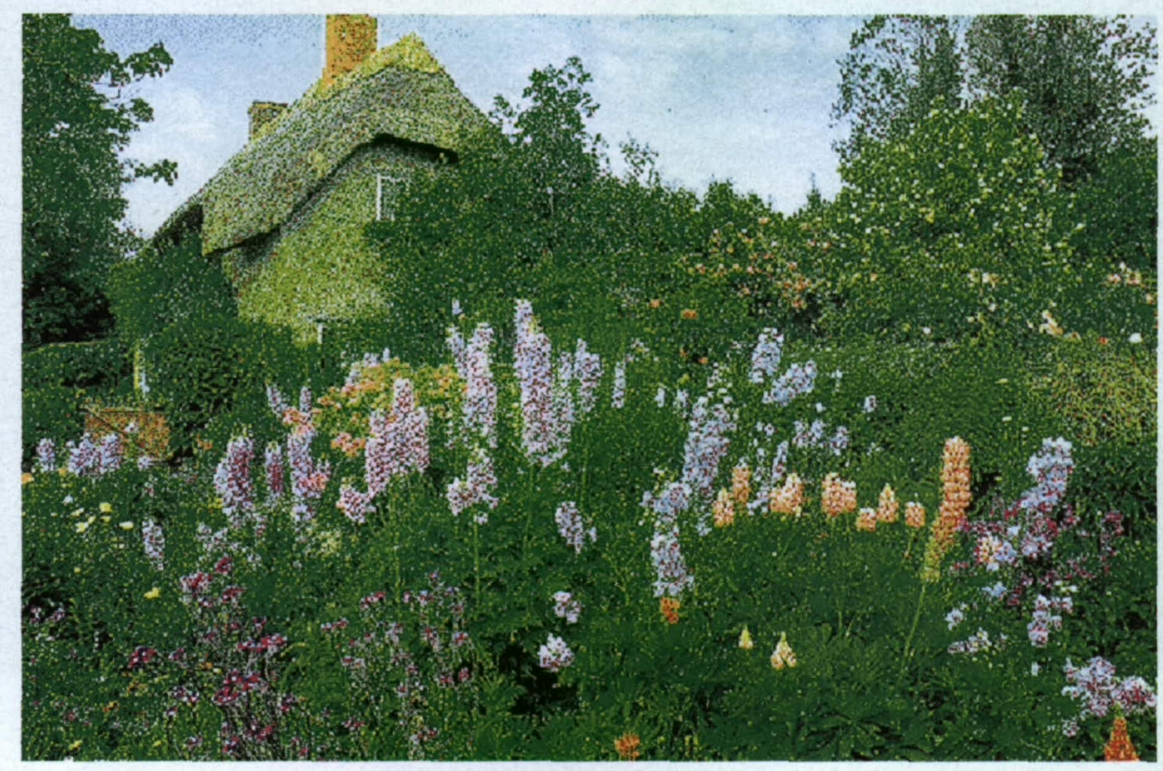

(b) 変換画像

口絵 7

すべての画素の色相を赤, 緑, 黄, 青, 茶, 紫, オレンジ, ピンクの 8 色 相に一致させるように変換してある. 輝度值 (明度值) は原画像のものを 保持している. 